\title{
STABILISASI TANAH LEMPUNG DENGAN BAHAN SERBUK KAYU TERHADAP KUAT TEKAN BEBAS
}

\author{
Abdul Muktadir \\ Program Studi Teknik Sipil Universitas Muhammadiyah Sorong \\ Jalan Pendidikan No 27 Kota Sorong, Propinsi Papua Barat \\ Email : abdmktdr18@gmail.com
}

\begin{abstract}
ABSTRAK
Tanah merupakan dasar dari suatu struktur bangunan. Setiap daerah memiliki karakteristik dan sifat-sifat tanah yang bervariasi. Seringkali terdapat beberapa sifat tanah yang buruk dan kurang menguntungkan untuk suatu konstruksi bangunan. Contoh beberapa sifat tanah yang perlu diperhatikan adalah plastisitas yang tinggi, kekuatan geser yang rendah, kemampatan atau perubahan volume dan kembang susut yang besar. Sangat penting untuk mengetahui permasalahan tanah tersebut, serta memberikan upaya untuk memperbaikinya. Pengujian ini bertujuan untuk mengetahui klasisifikasi tanah, indeks plastisitas tanah dan mengetahui pengaruh penambahan serbuk kayu terhadap sifat fisik tanah, serta mengetahui nilai kuat tekan bebas tanah dalam kondisi eksisting dan setelah dicampurkan serbuk kayu. Kadar air benda uji diambil dari hasil pemadatan proctor standar dengan variasi campuran serbuk kayu 0\%, 10\%, $15 \% 20 \%$ dan 25\%. Metode penelitian ini adalah dengan mengambil langsung sampel tanah di lokasi yang di telah di tetapkan kemudian melakukan pengujian di laboratorium.
\end{abstract}

Kata Kunci : stabilisasi tanah lempung ; serbuk kayu ; kuat tekan bebas 


\section{PENDAHULUAN}

\section{Latar Belakang}

Tanah merupakan dasar dari suatu struktur bangunan. Setiap daerah memiliki karakteristik dan sifat-sifat tanah yang bervariasi. Seringkali terdapat beberapa sifat tanah yang buruk dan kurang menguntungkan untuk suatu konstruksi bangunan. Contoh beberapa sifat tanah yang perlu diperhatikan adalah plastisitas yang tinggi, kekuatan geser yang rendah, kemampatan atau perubahan volume dan kembang susut yang besar. Sangat penting untuk mengetahui permasalahan tanah tersebut, serta memberikan upaya untuk memperbaikinya. Salah satu permasalahan yang dihadapi ialah kondisi tanah yang memiliki sifat yang kurang baik seperti memiliki sifat kembang susut yang sangat tinggi dan juga tanah yang sangat reaktif apabila tersiram oleh air dimana pada saat musim kemarau memiliki sifat yang sangat keras namun ketika di musim penghujan sifatnya menjadi lembek. Fenomena ini akan mengakibatkan konstruksi yang dibangun diatasnya menjadi tidak stabil. Hal tersebut akan terus berulang dan bermasalah apabila tanah dibawah konstruksi tidak di stabilisasi terlebih dahulu. Ada beberapa langkah yang dapat diambil untuk memperbaiki tanah labil. Pada penelitian ini, digunakan bahan tambah serbuk kayu untuk stabilisasi tanah. Pada lokasi penelitian yang berada di jalan belakang united tractor km 13 ditemui banyak jalan yang rusak, sehingga penulis tertarik melakukan stabilisasi tanah dengan menggunakan serbuk kayu karena dalam segi ekonomis penggunaan serbuk kayu sebagai zat tambahdan mengetahui nilai kekuatan tanah setelah stabilisasi pada lokasi tersebut.

\section{Tujuan Penelitian}

Penelitian ini bertujuan untuk mengetahui klasifikasi tanah, index plastisitasi tanah dan mengetahui pengaruh penambahan serbuk kayu terhadap sifat fisik tanah, serta mengetahui kuat tekan bebas tanah dalam kondisi eksisting dan setelah dicampurkan serbuk kayu.

\section{STATE OF THE ART}

Adapun penelitian terdahulu yang terkait dengan penelitian ini adalah sebagai berikut :

1. Menurut Rezki, A. (2014) dengan judul Kajian Kuat Tekan Bebas Pada Tanah Lempung Yang Distabilisasi dengan abu ampas tebu dan semen. jadi kesimpulannya adalah material abu sekam padi hanya efektif berfungsi pada variasi campuran $2 \% \mathrm{PC}+$ $4 \%$ ASP yaitu dengan nilai kuat tekan bebas sebesar $3,82 \% \mathrm{~kg} / \mathrm{cm}^{2}$ dan $3,64 \% \mathrm{~kg} / \mathrm{cm}^{2}$. Hasil penelitian ini menunjukkan penggunaan abu sekam padi tidak begitu di anjurkan.

2. Menurut Fadila, N. (2014) dengan judul Pengujian tekan bebas (unconfined compression test) pada stabilitas tanah lempung dengan campuran dan abu sekam padi. Jadi kesimpulannya bahwa material abu sekam padi hany efektif berfungsi pada variasi campuran 2\% PC $=3 \%$ ASP yaitu dengan nilai kuat tekan bebas sebesar $3,82 \mathrm{~kg} / \mathrm{cm}$ dan 3,64. Hasil penelitian ini menunjukkan penggunaan abu sekam padi fidak begitu di anjurkan.

3. Menurut Hairulla, H., Paresa, J., \& Cahyanti, T. W. A. (2014) dengan judul pemanfaatan limbah beton sebagai bahan stabilisasi tanah ekspanif terhadap nilai kuat tekan bebas guna perkuatan jalan lingkungan di kampung sota distrik sota perbatasan republic Indonesia-papua new guinea hasil pengujian kuat tekan juga mengalami peningkatan sesuai dengan perbaikan nilai qu pada tanah lempung ekspansif yang terstabilisasi dengan limbah beton. 
4. Menurut Maryati, M., \&Apriyanti, Y. (2016) dengan judul analisis perbandingan penggunaan limbah gypsum dengan semen sebagai bahan stabilisasi tanah lempung. Hasil pengujian perbedaan nilai penurunan konsolidasi keduanya adalah 159,2\%.

5. Menurut Mina, E., Kusuma, R. I., \& Ridwan, J.(2017) dengan judul stabilisasi tanah lempung menggunakan pasir laut dan pengaruhnya terhadap nilai kuat tekan bebas. Hasil penelitian dapat disimpulkan bahwa penggunaan pasir laut dengan persentase pasir laut sebesar 30\% adalah cukup baik untuk mengurangi nilai plastisitas, selain dapat meningkatkan daya dukung tanah berdasarkan nilai kuat tekan bebas (UCT)dengan kategori baik sebagai subgrade

\section{METODE}

\section{Tahapan Penelitian}

Tahapan penelitian yang digunakan adalah sebagai berikut :

1. Melakukan pengumpulan data

2. Survey lokasi dan pengambilan sampel

3. Melakukan pengujian sifat fisik tanah

4. Melakukan stabilisasi tanah lempung dengan serbuk kayu

5. Melakukan pengujian sifat fisik tanah setelah pencampuran dengan serbuk kayu

6. Melakukan analisis data kemudian mengambil kesimpulan.

Semua metode penulisan dan analisa dalam artikel ilmiah ini merujuk pada panduan penulisan tugas akhir Fakultas Teknik Universitas Muhammadiyah Sorong tahun 2014 (Pristianto, Amri, \& Rusdi, 2014).

\section{REFERENSI}

1. Rezki, A. (2014). Kajian Kuat Tekan Bebas Pada Tanah Lempung Yang Distabilisasi Dengan Abu Ampas Tebu Dan Semen. Jurnal Teknik Sipil USU, 3(2).

2. Fadilla, N. (2014). Pengujian Kuat Tekan Bebas (Unconfined Compression Test) Pada Stabilitas Tanah Lempung Dengan Campuran Semen dan Abu Sekam Padi. Jurnal Teknik Sipil USU, 3(2).

3. Hairullla, H., Paresa, J., \& Cahyanti, T. W. A. (2014). PEMANFAATAN LIMBAH BETON SEBAGAI BAHAN STABILISASI TANAH EKSPANSIF TERHADAP NILAI KUAT TEKAN BEBAS GUNA PERKUATAN JALAN LINGKUNGAN DI KAMPUNG SOTA DISTRIK SOTA PERBATASAN REPUBLIK INDONESIA-PAPUA NEW GIINEA. MUSTEK ANIM HA, 3(3), 212-225.

4. Pristianto, H., Amri, I., \& Rusdi, A. (2014, May 9). Pedoman Penulisan Tugas Akhir Fakultas Teknik Universitas Muhammadiyah Sorong 2014. http://doi.org/10.17605/OSF.IO/4VTJM.

5. Maryati, M., \& Apriyanti, Y. (2016). Analisis Perbandingan Penggunaan Limbah Gypsum Dengan Semen Sebagai Bahan Stabilisasi Tanah Lempung. In Forum Profesional Teknik Sipil(Vol. 4, No. 1). Bangka Belitung University.

6. Mina, E., Kusuma, R. I., \& Ridwan, J. (2017). STABILISASI TANAH LEMPUNG MENGGUNAKAN PASIR LAUT DAN PENGARUHNYA TERHADAP NILAI KUAT TEKAN BEBAS (Studi Kasus: Jalan Mangkualam Kecamatan CimangguBanten). Jurnal Fondasi, 6(2). 